\title{
SISTEM PAKAR DIAGNOSIS PENYAKIT IKAN GURAMI (OSPHRONEMUS GORAMY) MENGGUNAKAN CASE BASED REASONING
}

\author{
Adinda Rahmi Saraswati*1, Yudha Saintika ${ }^{2}$, Afandi Nur Aziz Thohari ${ }^{3}$, Ade Rahmat Iskandar ${ }^{4}$ \\ ${ }^{1}$ Program Studi S1 Informatika Institut Teknologi Telkom Purwokerto \\ ${ }^{2}$ Program Studi S1 Sitem Informasi Institut Teknologi Telkom Purwokerto \\ ${ }^{3}$ Program Studi S1 Rekaya Perangkat Lunak Institut Teknologi Telkom Purwokerto \\ ${ }^{4}$ Program Studi D3 Telekomunikasi Akademi Telkom Jakarta \\ Email: 115102003@st3telkom.ac.id, ${ }^{2}$ yudha@ittelkom-pwt.ac.id, ${ }^{3}$ afandi@ittelkom-pwt.ac.id, \\ 4ader@akademitelkom.ac.id \\ *Penulis Korespondensi
}

(Naskah masuk: 22 April 2019, diterima untuk diterbitkan: 28 Oktober 2019)

\begin{abstract}
Abstrak
Ikan Gurami (Osphronemus Goramy) merupakan ikan yang banyak dibudidayakan dan dikomsumsi masyarakat. Ikan ini menjadi sektor unggulan di beberapa wilayah kabupaten Banyumas. Ikan gurami yang dibudidayakan oleh masyarakat Banyumas, sebenarnya bukan tanpa hambatan. Dilansir dari portal berita online, pada Februari 2018 beredar bahwa berita mengenai petani Gurami merugi karena ribuan ikan Gurami indukan yang diternak mati terserang penyakit bakteri yaitu Aeromoniasis. Pakar yang menangani hal tersebut terbatas yaitu hanya 2 orang saja di wilayah Kabupaten Banyumas. Oleh karena itu, pada penelitian ini penulis membuat sistem pakar untuk mendiagnosis penyakit ikan Gurami yang disebabkan bakteri. Penelitian ini menggunakan metode Case Based Reasoning (CBR) dan Nearest Neighbor digunakan untuk mendapatkan solusi yang terbaik dari kasus yang di identifikasi. Metode CBR dilakukan dengan membandingkan kasus lama dengan kasus baru dan menghitung suatu nilai similarity kasus. Sistem dibangun dengan 13 gejala dan 3 penyakit ikan Gurami yang disebabkan bakteri. Setiap gejala masing-masing memiliki bobot yaitu 5, 3, dan 1 . Nilai similarity tertinggi dapat dijadikan kesimpulan untuk kasus yang paling mirip dengan diagnosis pakar. Sehingga dari kedua metode tersebut dapat dihasilkan sistem pakar yang dapat mendiagnosis dan menganalisis sesuai dengan nilai kemiripan gejala terhadap penyakit, serta menampilkan solusi penanganan dari penyakit yang didiagnosis. Hasil pengujian antar kasus dan sistem menggunakan perhitungan similarity mencapai nilai terbaik yaitu $100 \%$. Hasil pengujian akurasi sistem untuk diagnosis yang sesuai dengan pikiran pakar, memperoleh hasil sebesar 93,33\% dari 30 kasus yang diuji dengan sistem. Kesimpulan dari hasil tersebut adalah sistem dapat dikatakan layak untuk mendiagnosis penyakit Gurami yang disebabkan bakteri sesuai dengan yang dipikirkan pakar.
\end{abstract}

Kata kunci: case based reasoning, nearest neighbor, similarity, sistem pakar

\section{EXPERT SYSTEM FOR DIAGNOSIS OF GURAMI FISH (OSPHRONEMUS GORAMY) DISEASE USING CASE BASED REASONING}

\begin{abstract}
Gurami (Osphronemus Goramy) is a fish that is widely cultivated and consumed by the community. This fish is a leading sector in several regions of Banyumas district. Gouramy which is cultivated by the Banyumas people, is actually not without obstacles. One obstacle for gouramy breeders is a disease caused by bacteria. Reporting from the online news portal, circulating in February 2018 circulated that news about Gurami farmers was losing money because thousands of broodstock fish that had been raised to death were attacked by bacterial diseases, namely Aeromoniasis. Experts who handle this are limited, namely only 2 people in the Banyumas Regency. In this study the authors made an expert system to diagnose Gurami fish disease caused by bacteria. This study uses the Case Based Reasoning (CBR) and Nearest Neighbor methods used to get the best solution from the identified case. The CBR method compares the old case with the new case and calculates a case similarity value. The system was built with 13 symptoms and 3 Gurami diseases caused by bacteria. Each symptom each has a weight of 5, 3, and 1. The highest similarity value can be used as a conclusion for the case most similar to the expert diagnosis. So that from these two methods an expert system can be produced that can diagnose and analyze according to the similarity of symptoms to the disease, as well as display solutions to the treatment of diagnosed diseases. The test results are between cases and the system uses the similarity calculation to achieve the best value
\end{abstract}


of $100 \%$. The results of the system accuracy test for diagnoses that are in accordance with the expert's mind, obtained results of $93.33 \%$ from 30 cases tested with the system. The conclusion of these results is that the system can be said to be feasible to diagnose Gurami disease caused by bacteria according to what experts think.

Keywords: case based reasoning, expert system, nearest neighbor, similarity

\section{PENDAHULUAN}

Ikan Gurami merupakan ikan air tawar asli dari Indonesia tepatnya berasal dari perairan daerah Sunda (Jawa Barat) yang memilik nama latin Osphronemus Goramy (Danuri, 2010). Di Jawa, ikan Gurami dinamakan Gurami sesuai dengan nama latinnya. Pemilihan ikan gurami sebagai objek penelitian dikarenakan ikan yang banyak dibudidayakan dan dikomsumsi masyarakat Indonesia ini menjadi sektor unggulan di beberapa wilayah Kabupaten Banyumas (Sumarwoto, 2018). Purwokerto memiliki kawasan Minapolitan tempat untuk perkembangan ikan Gurami yang disebut "Kebang Cirawas", terdiri dari beberapa wilayah yaitu Kedungbanteng, Kembaran, Kemranjen, Baturaden, Ajibarang, Cilongok, Sokaraja, Karanglewas dan Sumpiuh. Gambar 1 merupakan data produksi perikanan kabupaten Banyumas. Data tersebut digunakan sebagai alasan dipilihnya ikan Gurami dalam penelitian penulis.

TOTAL PRODUKSI PERIKANAN KAB.BANYUMAS

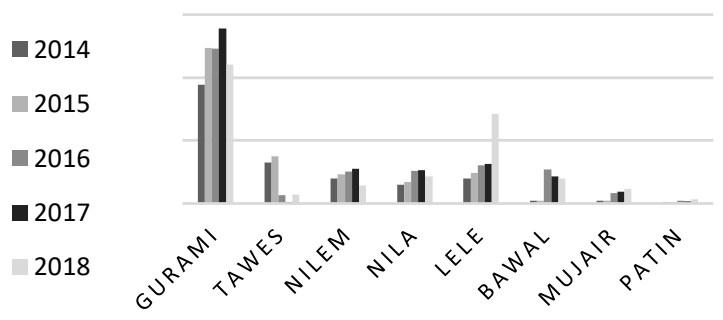

Gambar 1. Gambar Produksi Perikanan Kab. Banyumas

Ikan gurami yang dibudidayakan oleh masyarakat Banyumas, sebenarnya bukan tanpa hambatan. Salah satu hambatan yang menjadi momok bagi peternak gurami adalah penyakit yang disebabkan oleh bakteri. Pengaruh cuaca yang berubah-ubah dan pemeliharaan yang tidak sehat dapat menimbulkan penyakit pada ikan Gurami, terutama penyakit yang disebabkan oleh bakteri. Dampak dari timbulnya penyakit dapat menyebabkan banyaknya ikan yang mati sehingga membuat petani ikan Gurami mengalami penurunan pendapatan hingga kerugian, terutama bagi orang baru/awam yang mencoba membudidayakan ikan Gurami sebagai peluang bisnisnya. Dilansir dari portal berita online, pada Februari 2018 beredar berita mengenai petani Gurami yang merugi karena ribuan ikan Gurami indukan yang diternak mati terserang bakteri (Wuryanti, 2018). Kepala Dinas Peternakan dan Perikanan Kabupaten Banyumas bapak Sugiyatno mengatakan kasus kematian ikan Gurami di wilayah Purwokerto telah terjadi dari November 2017 (Wuryanti, 2018). Banyaknya ikan gurami yang mati diakibatkan kurangnya pengetahuan peternak untuk mengidentifikasi penyakit gurami sejak dini, sehingga terlambat melakukan penanganan yang berdampak kerugian dan penurunan pendapatan. Ikan Gurami yang diternak atau dibudidayakan harus selalu diperhatikan lingkungan dan kesehatannya agar aman dalam pemeliharaan dan terutama untuk konsumsi. Apabila Gurami terserang penyakit, peternak atau pembudidaya mengunjungi UPT BPBAT (Unit Pelaksanaan Teknis Balai Pengembangan Budidaya Air Tawar) untuk melakukan tanya jawab mengenai gejala dan penyakit yang dialami ikan Gurami sehingga mendapat informasi dan penangannya. Pakar yang menangani masalah Gurami ini terbatas yaitu hanya dua orang saja di wilayah Banyumas, dibandingkan kasus yang menyerang Gurami seperti kematian yang disebabkan bakteri. Berdasarkan permasalahan tersebut maka pada penelitian ini akan dibangun sebuah sistem pakar untuk mendiagnosis penyakit ikan gurami.

Metode yang digunakan pada penelitian ini adalah Case Based Reasoning yaitu metode yang digunakan untuk menyelesaian suatu permasalahan yang baru dengan didasari pada knowledge dari kasus sebelumnya (Candra \& Jefri, 2017). Sistem inferensi menggunakan Nearest Neighbor untuk menentukan atau menghitung suatu nilai similarity kasus gejala. Sehingga dari kedua metode tersebut dapat dihasilkan sistem pakar yang dapat mendiagnosis dan menganalisis sesuai dengan nilai kemiripan atau kekauratan gejala terhadap penyakit, serta menampilkan solusi penanganan dari penyakit yang didiagnosis.

Metode yang digunakan pada penelitian ini adalah Case Based Reasoning (CBR), sistem pakar dengan menggunakan metode ini cocok untuk mendapatkan solusi berdasarkan suatu kasus dalam menganalisis diagnosa penyakit ikan Gurami yang disebabkan oleh bakteri. Berikut penelitian sebelumnya yang menjadi alasan digunakannya metode CBR dan Nearest Neighbor yaitu sistem diagnosa kegagalan budidaya ikan Mas menggunakan CBR dan Nearest Neighbor dengan bukti hasil nilai perbandingan sama dengan sistem serta sesuai dengan yang dipikirkan pakar (Candra \& Jefri, 2017). 
Berikut ini merupakan rangkuman dari kajian teori yang digunakan dalam penelitian ini:

\subsection{Sistem Pakar}

Menurut buku kecerdasan buatan oleh Andri Kristanto, Sistem pakar merupakan program kecerdasan buatan yang menggabungkan basis pengetahuan (knowledge base) dengan sistem inferensi (Amonius, Hardi, \& Muhammad, 2018). Sistem pakar merupakan aplikasi berbasis komputer untuk menyelesaikan suatu masalah yang tidak bisa diselesaikan oleh orang awam atau orang yang kurang berpengalaman dalam hal tertentu (Murien \& Hartati, 2017).

Struktur sistem pakar mengenai sudut pandang lingkungan (environment) dalam sistem terdapat dua lingkungan yang dipisahkan dengan garis putus-putus di tengah yaitu lingkungan konsultasi dan lingkungan pengembangan. Lingkungan konsultasi untuk melakukan konsultasi dan mendapat nasehat pakar sebagai tujuan utamanya. Sedangkan, lingkungan pengembangan merupakan bagian yang dimiliki perancang atau pembangun sistem pakar untuk memodifikasi, meninjau, membangun komponen dan memasukkan pengetahuan hasil akuisisi pengetahuan ke dalam basis pengetahuan (Minarni, Warman, \& Wenda, Case-Based Reasoning (Cbr) Pada Sistem Pakar Identifikasi Hama Dan Penyakit Tanaman Singkong Dalam Usaha Meningkatkan Produktivitas Tanaman Pangan, 2017).

\subsection{Metode Case Based Reasoning}

Case Based Reasoning (CBR) merupakan suatu pendekatan untuk menyelesaikan masalah atau mendapatkan solusi dari permasalahan sebelumnya. Mencari pemecahan masalah didasarkan knowledge dan kasus sebelumnya (Candra \& Jefri, 2017).

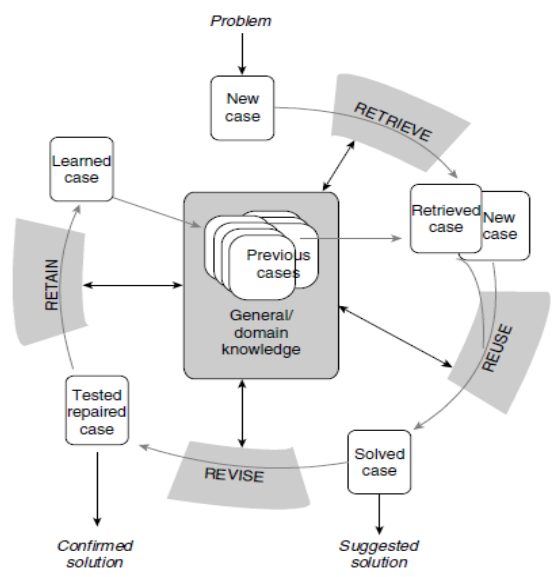

Gambar 2. Case Based Reasoning Life Cycle (Arman, Danang, \& Imrona, 2017)

Gambar 2 secara umum merupakan siklus CBR memiliki tahapan-tahapan sebagai berikut (Nasution, Hasibuan, \& Ramadhani, 2017) :
a. Retrieve

Mendapatkan kasus sebelumya yang paling mirip (similar) dengan kasus baru.

b. Reuse

Menggunakan solusi/informasi dari kasus yang didapat untuk memecahkan masalah. Perbedaan antara kasus sebelumnya dengan kasus baru, keputusan dari yang diambil dapat menjadi kasus baru.

c. Revise

Meninjau atau merevisi (jika dibutuhkan) kembali usulan solusi.

\section{d. Retain}

Menyimpan informasi atau pengalaman tersebut yang mungkin berguna untuk solusi atau pemecah masalah yang akan datang.

\subsection{Nearest Neighbor}

Nearest Neighbor (NN) digunakan untuk melakukan perhitungan nilai kemiripan tertinggi pencarian solusi dengan membandingkan kasus baru dan kasus lama yang ada di case base (Kusrini \& Luthfi, 2009). Rumus untuk menghitung kedekatan antar kasus menggunakan similarity, sebagai berikut (Kusrini \& Luthfi, 2009) :

$$
\operatorname{Similarity}(T, S)=\frac{\sum_{i=1}^{n} f(T i, S i) * w i}{w i}
$$

$$
\begin{array}{ll}
\text { Keterangan: } \\
\mathrm{T} \quad=\text { kasus baru } \\
\mathrm{S} \quad \quad=\text { kasus yang ada dalam penyimpanan } \\
\mathrm{n} & =\text { jumlah atribut dalam setiap kasus } \\
\mathrm{i} & =\text { atribut individu antara } 1 \mathrm{s.d} \mathrm{n} \\
\mathrm{f} & =\text { fungsi similarity } \text { atribut } i \text { antara kasus } \\
& \quad \text { dan kasus } \mathrm{S} \\
\mathrm{w} & =\text { bobot yang diberikan pada atribut ke- } i
\end{array}
$$

\section{METODE PENELITIAN}

Sistem ini dirancang sebagai aplikasi sistem pakar yang dapat mendiahnosis penyakit ikan Gurami yang disebabkan bakteri. Cara kerja sistem pakar ini adalah pembudidaya memasukkan data kunjungan dan memilih (centang) gejala yang ada pada sistem. Data gejala yang sudah dimasukkan akan di proses oleh CBR dan similarity NN.

Gambar 3 merupakan perhitungan similarity digunakan untuk mendapatkan nilai similarity kesamaan kasus yang paling tinggi, nilai kemiripan tertinggi digunakan sebagai solusi pemecahan masalah atau disebut juga reuse. Menemukan solusi yang mirip seperti yang terdapat di Gambar 3. merupakan tahap reuse, karena solusi yang paling mirip digunakan kembali sebagai solusi dari pemecahan masalah. Apabila nilai similarity dengan threshold $<70 \%$ maka dapat dilakukan proses revisi. Proses revisi dilakukan untuk meninjau atau merevisi (jika dibutuhkan) kembali usulan solusi, apabila ditemukan solusi baru. 


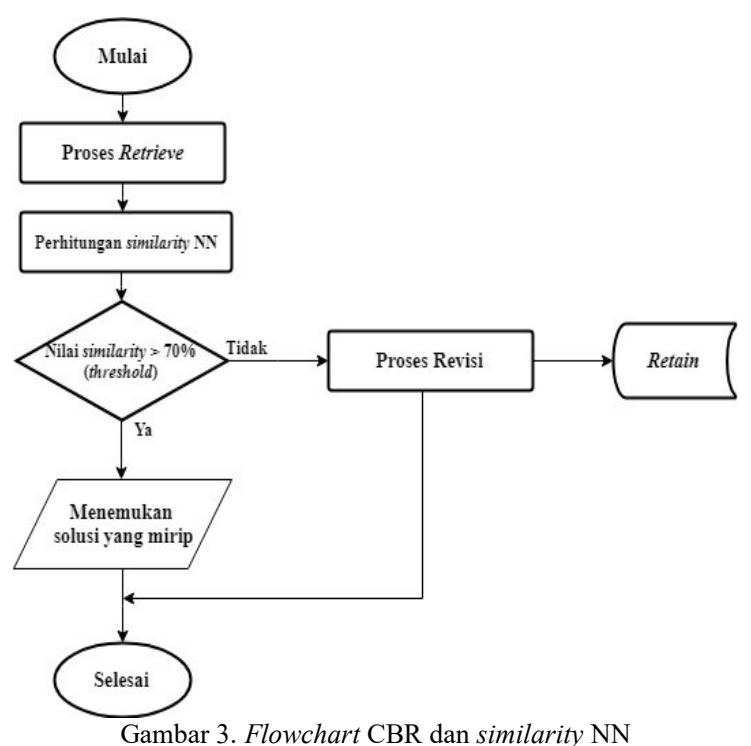

Tabel 1. Threshold Acuan Pakar

\begin{tabular}{ll} 
Threshold & Keterangan \\
\hline $\begin{array}{l}\text { Threshold } \\
>70 \%\end{array}$ & $=$ Diagnosis sesuai dengan diagnosis pakar \\
Threshold & $=$ Diagnosis sesuai dengan pakar \\
$<70 \%$ s.d & (alternatif atau optional) \\
$>50 \%$ & \\
Threshold & $=$ Diagnosis tidak sesuai dengan diagnosis pakar \\
$<50 \%$ & (terdiagnosis penyakit selain penyakit bakteri)
\end{tabular}

Tabel 1. merupakan Threshold atau nilai diagnosis dari pertimbangan pakar untuk mengetahui hasil diagnosis penyakit yang dialami Gurami.

\subsection{Representasi Kasus}

Representasi kasus digunakan untuk menjelaskan hasil informasi yang didapat dan disimpan untuk basis kasus dalam bentuk tertentu. Penulis menggunakan bentuk tabel untuk merepresentasikan informasi dari gejala penyakit bakteri ikan gurami yang telah didapat berdasarkan wawancara dan diskusi dengan pakar. Bobot gejala yang digunakan yaitu 1,3, dan 5. Bobot tersebut berdasarkan hasil pertimbangan pakar dan meninjau dari jurnal yang terkait dengan penelitian ini. Berikut dapat dilihat pada Tabel 2. dan Tabel 3.

\begin{tabular}{cccccccc}
\multicolumn{7}{c}{ Tabel 2. Representasi Kasus } \\
\hline Kasus & K01 & K02 & K03 & K04 & K05 & K06 & K07 \\
\hline G/P & P01 & P02 & P03 & P01 & P02 & P03 & P02 \\
G01 & X & X & X & X & X & & \\
G02 & X & X & X & X & X & X & X \\
G03 & X & X & X & X & X & & \\
G04 & X & X & X & X & X & & \\
G05 & X & X & X & & & & \\
G06 & X & & X & X & X & X & X \\
G07 & X & & & X & X & & \\
G08 & X & X & & & X & & \\
G09 & X & & & X & & X & X \\
G10 & & & X & & & & \\
G11 & & X & & & & X & \\
G12 & X & & & & X & X & X \\
G13 & X & & X & X & & & X \\
\hline
\end{tabular}

Keterangan :

Tanda "X" = Gejala yang dialami setiap kasus

\begin{tabular}{cl}
\multicolumn{2}{c}{ Tabel 3. Data Gejala Penyakit } \\
\hline Kode & \multicolumn{1}{c}{ Nama Gejala } \\
Gejala & \\
\hline G1 & Nafsu makan menurun \\
G2 & Ikan tampak lemah \\
G3 & Ikan kurang responsive terhadap lingkungan \\
G4 & Ekses lendir \\
G5 & Warna insang pucat \\
G6 & Warna tubuh pucat \\
G7 & Keluar gelembung udara dari insang / mrupus \\
G8 & Terdapat ruam kemerahan di tubuh \\
G9 & Kerusakan pada sirip \\
G10 & Perut lembek dan bengkak (dropsy) \\
G11 & Furunculus (bisul) di permukaan tubuh \\
G12 & Mata menonjol (exopthalmia) \\
G13 & Ulser / borok pada tubuh \\
\hline
\end{tabular}

\subsection{Implementasi Metode}

A. Proses retrieve

Proses ini digunakan untuk mendapatkan kasus yang paling mirip (similar) antara kasus sebelumya yang terdapat di basis kasus (case base) sistem dengan kasus yang ditargetkan. Kasus yang paling mirip ini ditentukan dengan cara analisis kasus sebelumnya dengan kasus yang ditargetkan dan disesuaikan dengan bobot gejala yang didapat dari pakar. Tabel 4. sebagai salah satu contoh kasus.

Tabel 4. Menentukan kerimiripan anatar kasus

\begin{tabular}{|c|c|c|c|c|c|}
\hline KG & Nama Gejala & $\mathbf{K X}$ & K04 & Nilai $S$ & B \\
\hline G1 & Nafsu makan menurun & $\checkmark$ & $\checkmark$ & 1 & 3 \\
\hline G2 & Ikan tampak lemah & $\checkmark$ & $\checkmark$ & 1 & 1 \\
\hline G3 & $\begin{array}{l}\text { Ikan kurang } \\
\text { responsive terhadap } \\
\text { lingkungan }\end{array}$ & $\checkmark$ & $\checkmark$ & 1 & 1 \\
\hline G4 & Ekses lendir & $\checkmark$ & $\checkmark$ & 1 & 3 \\
\hline G5 & Warna insang pucat & & & 0 & 0 \\
\hline G6 & Warna tubuh pucat & $\checkmark$ & $\checkmark$ & 1 & 3 \\
\hline G7 & $\begin{array}{l}\text { Keluar gelembung } \\
\text { udara dari insang / } \\
\text { mrupus }\end{array}$ & $\checkmark$ & $\checkmark$ & 1 & 3 \\
\hline G8 & $\begin{array}{l}\text { Terdapat ruam } \\
\text { kemerahan di tubuh }\end{array}$ & $\checkmark$ & & 0 & 0 \\
\hline G9 & Kerusakan pada sirip & $\checkmark$ & $\checkmark$ & 1 & 3 \\
\hline G10 & $\begin{array}{l}\text { Perut lembek dan } \\
\text { bengkak (dropsy) }\end{array}$ & & & 0 & 0 \\
\hline G11 & $\begin{array}{l}\text { Furunculus (bisul) di } \\
\text { permukaan tubuh }\end{array}$ & & & 0 & 0 \\
\hline G12 & $\begin{array}{l}\text { Mata menonjol } \\
\text { (exopthalmia) }\end{array}$ & & & 0 & 0 \\
\hline G13 & $\begin{array}{l}\text { Ulser / borok pada } \\
\text { tubuh }\end{array}$ & $\checkmark$ & $\checkmark$ & 1 & 5 \\
\hline
\end{tabular}

Setelah menentukan kemiripan kasus sebelumnya dengan kasus baru, kemudian antara kasus tersebut dihitung nilai kemiripannya sebagai berikut : 


$$
\begin{aligned}
\text { Similarity }= & \frac{(1 * 3)+(1 * 1)+(1 * 1)+(1 * 3)+(1 * 3)+(1 * 3)+(1 * 3)+(1 * 5)}{3+1+1+3+3+3+3+5} \\
& =\frac{22}{22} \\
& =1 * 100 \\
& =100 \%
\end{aligned}
$$

\section{B. Proses reuse}

Solusi identifikasi yang dapat digunakan pada proses reuse yaitu diambil dari kasus dengan nilai kemiripan (similarity) tertinggi. Berdasarkan proses sebelumnya, diperoleh kasus dengan nilai kemiripan tertinggi yaitu kasus K04 yang mengarah pada penyakit Aeromoniasis (P01) dengan kemiripan sebesar $100 \%$. Pada table 5 dapat dilihat bahwa hasil yang diperoleh dapat digunakan karena nilai kemiripan lebih dari threshold yang ditentukan yaitu $>70 \%$.

\begin{tabular}{ccc}
\multicolumn{3}{c}{ Tabel 5. Hasil Perbandingan Kasus } \\
\hline Kasus & ID Penyakit & Similaritas \\
\hline KX-K01 & P01 & $80,64 \%$ \\
KX-K02 & P02 & $53,84 \%$ \\
KX-K03 & P03 & $80 \%$ \\
KX-K04 & P01 & $100 \%$ \\
KX-K05 & P02 & $64,28 \%$ \\
KX-K06 & P03 & $52,94 \%$ \\
KX-K07 & P02 & $50 \%$ \\
\hline
\end{tabular}

\section{Proses revise}

Proses revise merupakan adapatasi dari proses reuse apabila kasus belum berhasil diidentifikasi. Revise dapat terjadi apabila nilai kemiripan kurang dari threshold yang ditentukan. Kasus yang belum berhasil akan dilakukan revisi oleh pakar. Pakar akan merevisi bobot gejala atau kasus sesuai gejala yang ada pada basis kasus sistem pakar ini. Berdasarkan kasus diatas, maka proses revise tidak digunakan.

\section{Proses retain}

Proses retain digunakan untuk menyimpan kasus atau informasi ke dalam basis pengetahuan sistem, sehingga nantinya dapat digunakan untuk mengidentifikasi kasus baru. Kasus yang akan disimpan, didiskusikan terlebih dahulu bersama pakar.

\section{HASIL DAN PEMBAHASAN}

Pada tahap ini pengujian dilakukan dengan perhitungan akurasi dari data kasus yang sudah diidentifikasi berapa jumlah yang sesuai dan tidak sesuai dengan diagnosis pakar. Pengujian dilakukan dalam dua tahap yaitu pengujian pada sistem pakar untuk nilai kemiripan (similarity) sesuai dengan kasus gejala yang sama (casebase) dan pengujian perhitungan akurasi sistem dengan 30 kasus sebagai data uji. Tabel 6. merupakan hasil pengujian perhitungan tahap pertama dan berhasil mendapatkan nilai similaritas $100 \%$.

\begin{tabular}{cccc}
\multicolumn{5}{c}{ Tabel 6. Hasil Pengujian Similaritas Gejala Sama } \\
\hline ID & Kode Gejala & ID & $\boldsymbol{S}$ \\
(K) & (P) & \\
\hline K01 & G1,G2,G3,G4,G5,G6,G7,G8,G9,G1 & P01 & $100 \%$ \\
& 0, G13 & & \\
K02 & G1,G2,G3,G4,G5,G9,G12 & P02 & $100 \%$ \\
K03 & G1,G2,G3,G4,G5,G6,G11,G13 & P03 & $100 \%$ \\
K04 & G1, G2,G3,G4,G5,G6,G7,G9,G13 & P01 & $100 \%$ \\
K05 & G1,G2,G3,G4,G6,G7,G8,G12 & P02 & $100 \%$ \\
K06 & G2,G6,G9,G11,G12 & P03 & $100 \%$ \\
K07 & G2,G6,G9,G12 & P02 & $100 \%$
\end{tabular}

Tabel 6 merupakan rekapitulasi hasil pengujian kepakaran. Pengujian kepakaran dilakukan dengan menguji 30 kasus yang didiagnosis dengan sistem, kemudian hasil diagnosis sistem di sesuaikan dengan diagnosis pakar. Hasil pengujian kepakaran digunakan untuk menghitung nilai akurasi sistem.

\begin{tabular}{cccc}
\multicolumn{4}{c}{ Tabel 7. Rekapitulasi Hasil Pengujian Kepakaran } \\
\hline No. & Jenis Penyakit & $\begin{array}{c}\text { Jumlah } \\
\text { Data } \\
\text { Uji }\end{array}$ & $\begin{array}{c}\text { Jumlah } \\
\text { Identifikasi } \\
\text { Benar }\end{array}$ \\
\hline 1. & Aeromoniasis/Penyakit Borok & 24 & 23 \\
2. & Mycobacteriosis/Fish TB & 3 & 3 \\
3. & Nocardiosis / Gill Tuberculosis & 3 & 2 \\
& Jumlah & 30 & 28 \\
\hline
\end{tabular}

Tabel 7 merupakan rekapitulasi hasil pengujian kepakaran tersebut kemudian dilakukan uji kelayakan sistem atau perhitungan akurasi menggunakan confusion matrix (Witten \& Frank, 2005).

$$
\text { Akurasi }=\frac{T P+T N}{T P+T N+F P+F N} \times 100 \%
$$

Tabel 8 Merupakan hasil pengujian confusion matrix untuk dihitung akurasi kelayakan sistem pakar ini dan berdasarkan data yang didapatkan sebelumnya di Tabel 7. Hasil akurasi baik menurut pakar yaitu apabila nilai akurasi $>80 \%$.

\begin{tabular}{cccccc}
\multicolumn{4}{c}{ Tabel 8. Hasil Pengujian } & \multicolumn{5}{c}{ Confusion Matrix } \\
\hline Jenis Identifikasi & TP & TN & FN & FP \\
\hline $\begin{array}{c}\text { Penyakit ikan } \\
\begin{array}{c}\text { Gurami yang } \\
\text { disebabkan bakteri }\end{array}\end{array}$ & 28 & 0 & 0 & 2 \\
\hline
\end{tabular}

$$
\begin{aligned}
\text { Akurasi } & =\frac{28+0}{28+0+0+2} \times 100 \% \\
& =\frac{28}{30} \times 100 \% \\
& =93,33 \%
\end{aligned}
$$

Hasil perhitungan akurasi sistem yaitu sebesar 93,33\%. Berdasarkan hasil perhitungan tersebut, sistem pakar diagnosis penyakit ikan Gurami (yang disebabkan bakteri) dapat mendiagnosis atau mengidentifikasi penyakit dengan cukup baik. Nilai tersebut cukup 
memuaskan karena mampu mencapai rata-rata minimum kesesuian pakar dan berdasarkan acuan dari analisis jurnal sebelumnya. Berdasarkan penelitian sebelumnya, hasil tingkat akurasi penelitian milik Arman et al sebesar 92\% dalam penelitian yang berjudul "Analisis dan Implementasi Sistem Pakar dengan Metode Case Based Reasoning dan Rule Based Reasoning (Studi Kasus: Diagnosis Penyakit Demam Berdarah)". Berdasarkan nilai tersebut, penilaiannya berpredikat cukup memuaskan karena klasifikasi minimum yang ditentukan oleh WHO dapat terpenuhi, serta mampu rata-rata kemampuan dokter di Indonesia dalam mendiagnosis demam berdarah dapat tercapai (Arman, Danang, \& Imrona, 2017). Dalam penelitian murien yang berjudul Sistem Penalaran "Berbasis Kasus Untuk Pendukung Diagnosis Gangguan Penyakit Pada Unggas" menghasilkan tingkat akurasi sebesar 93,33\% dan sistem tersebut berhasil mengidentifikasi penyakit dengan baik (Murien \& Hartati, 2017). Minarni et al, dalam penelitiannya yang berjudul "Implementasi CaseBased Reasoning Sebagai Metode Inferensi Pada Sistem Pakar Identifikasi Penyakit Tanaman Jagung" memperoleh hasil tingkat akurasi sistem sebesar $74,63 \%$. Nilai tersebut dalam penelitiannya menunjukkan bahwa sistem pakar identifikasi penyakit tanaman jagung menggunakan inferensi CBR dapat mengidentifikasi penyakit tanaman jagung dengan baik (Minarni, Warman, \& Yuhendra, 2018).

Berdasarkan penelitian sebelumnya, bahwa menggunakan metode Case Based Reasoning dan Nearest Neighbor dalam memperhitungkan kemiripan kasus yaitu cukup baik dengan dibuktikan dengan hasil tingkat akurasi sistem. Hal ini sebanding dengan kelebihan neural networks yang dapat memperhitungkan kemiripan kasus lama dengan kasus baru dengan baik.

\section{KESIMPULAN DAN SARAN \\ 4.1 Kesimpulan}

Berdasarkan hasil penelitian, perancangan dan implementasi sistem, dapat disimpulkan sebagai berikut :

1. Hasil penelitian implementasi metode CBR dalam sistem pakar ini yaitu dengan memperhitungkan kemiripan antara kasus sebelumnya dan kasus baru. Hasil perhitungan dengan nilai tertinggi menunjukan identifikasi penyakit Aeromoniasis terhadap basis kasus K04 yaitu sebesar $100 \%$.

2. Penelitian ini menghasilkan aplikasi sistem pakar diagnosis penyakit ikan Gurami yang disebabkan bakteri menggunakan metode Cased Based Reasoning dan Nearest Neighbor untuk menghitung nilai kemiripan kasus dengan threshold $>70 \%$. Berdasarkan 30 kasus yang diuji dalam pengujian kepakaran, terdapat 28 kasus yang sesuai dengan akurasi sistem sebesar 93,33\% dan 2 kasus yang tidak sesuai (6,67\%). Berdasarkan hasil perhitungan tersebut, sistem pakar diagnosis penyakit ikan Gurami (yang disebabkan bakteri) dapat mendiagnosis atau mengidentifikasi penyakit dengan baik. Dalam sistem pakar ini, proses revise belum diterapkan secara otomatis sehingga apabila terdapat perbaikan solusi harus menemui pakar terlebih dahulu untuk meninjau kembali solusi tersebut dengan persetujuan pakar.

\subsection{Saran}

Saran-saran untuk penelitian lanjutan adalah sebagai berikut:

1. Menggunakan metode lainnya untuk hasil yang lebih akurat.

2. Menambahkan lebih banyak jenis ikan dan penyakit agar sistem pakar ini dapat mendiagnosis jenis ikan dan penyakit lainnya.

3. Menerapkan proses revise secara otomatis dalam sistem agar sistem kepakaran dapat lebih sempurna.

4. Perlu mengembangkan sistem pakar ini agar dapat digunakan dengan sempurna.

\section{DAFTAR PUSTAKA}

ARMAN, D. J., DANANG, J., \& IMRONA, M. (2017). Based Reasoning Dan Rule Based Reasoning ( Studi Kasus : Diagnosis Penyakit Demam Berdarah ) Analysis and Implementation Expert System With Case Based Reasoning and Rule Based Reasoning Methods ( Case Study : Diagnosis of Dengue Fever Disease ). $e$ Proceeding of Engineering, 4(2), 32693276.

DANURI, S. (2010). Sukses Budi Daya Gurami. Yogyakarta: Pustaka Baru Press.

SUMARWOTO. (2018). Jateng Antaranews. Retrieved Maret 28, 2018, from https://jateng.antaranews.com/detail/budid aya-ikan-gurami-andalan-pemkabbanyumas-.html

WURYANTI, P. (2018). Anatara Jateng. Retrieved Maret 28, 2018, from https://jateng.antaranews.com/berita/18879 5/ribuan-ikan-gurami-mati-terserangbakteri-petani-banyumas-merugi-video

CANDRA, R. M., \& JEFRI, S. W. (2017). Sistem Diagnosa Kegagalan dalam Budidaya Ikan Konsumsi Air Tawar dengan Menggunakan Metode Case Based Reasoning. Sains, Teknologi dan Industri, 14(2), 144-149.

AMONIUS, A., HARDI, S., \& MUHAMMAD, S. (2018). Perancangan Aplikasi Sistem Pakar Mendoagnosa Penyakit Hemofilia Pada Manusia Menerapkan Metode Case Based Reasoning. Pelita Informatika, 17, 24-29. 
MURIEN, N., \& HARTATI, S. (2017). Sistem penalaran berbasis kasus untuk pendukung diagnosis gangguan penyakit pada unggas (Case Based Reasoning System to Support Diagnosis of Diseases in Poultry). Jurnal Informatika dan Komputer (JIKO), Vol. 2, No. 1, 50-57.

MINARNI, WARMAN, I., \& WENDA, H. (2017). Case-Based Reasoning (Cbr) Pada Sistem Pakar Identifikasi Hama Dan Penyakit Tanaman Singkong Dalam Usaha Meningkatkan Produktivitas Tanaman Pangan. Jurnal TEKNOIF, 5(1), 41-47.

NASUTION, S. W., HASIBUAN, N. A., \& RAMADHANI, P. (2017). Sistem Pakar Diagnosa Anoreksia Nervosa Menerapkan Metode Case Based Reasoning. KOMIK (Konferensi Nasional Teknologi Informasi dan Komputer), 1, 52-56.

MINARNI, WARMAN, I., \& YUHENDRA. (2018). Implementasi Case-Based Reasoning Sebagai Metode Inferensi Pada Sistem Pakar Identifikasi Penyakit Tanaman Jagung. TEKNOIF, 6 .

KUSRINI, \& LUTHFI, E. (2009). Algoritma Data Mining. Yogyakarta: Andi Offset.

WITTEN, H. I., \& FRANK, E. (2005). Data Mining : Practical Machine Learning Tools And Techniques (2 ed.). San Francisco: Morgan Kaufmann. 
Halaman ini sengaja dikosongkan 